\title{
A KÖZÚTI ÁRUSZÁLLÍTÁS ÉS SZÁLLÍTMÁNYOZÁS KIHÍVÁSAI NAPJAINKBAN
}

\author{
Oláh Judit
}

\begin{abstract}
Absztrakt: Kutatásomban megvizsgáltam a közúti fuvarozás és szállitmányozás magyar gazdaságban elfoglalt helyét és annak jelentőségét, ismertetve a belföldi és nemzetközi áruszállitásra vonatkozó szabályozásokat, azok fontosságát a hatékony szállitmányozás érdekében. Hangsúlyt kapnak a szállítmányozási tevékenység során jelentkező kihívások, amelyekkel csak megfelelö ismeretek birtokában képesek megbirkózni a fuvarszervező szakemberek. Megvizsgáltam az utóbbi években lezajló változásokat és az azokhoz való alkalmazkodás lehetőségeit, módjait. Elemeztem a 2013-ban bevezetett elektronikus útdij hatásait az ágazatra, annak elönyeivel és nehézségeivel együtt.

Abstract: The relevance and importance of the road transportation and forwarding were investigated detailing the regulation relating to the inland and international transportation of goods, and their significance for the sake of efficient transportation. Challenges appearing during the transportation processes were emphasized, which have to be coped with by experts only with special knowledge. The changes of the past years and moreover, the opportunities and methods were examined for harmonizing with them. The effects of the electronic toll introduced in 2013 were analyzed on the sector altogether with its advantages and difficulties
\end{abstract}

Kulcszsavak: közúti szállítmányozás, fuvarozás, közút, elektronikus-útdij

Keywords: road tarnasportation, forwarding, public road, electronic toll

\section{Bevezetés}

A napjainkra jellemző felgyorsult információáramlás, fokozódó verseny és a technológiai fejlődés egyre nagyobb kihívások elé állítja az emberiséget, amelyek megkívánják az egyének megfelelö felkészültségét területtől függetlenül. A logisztikai folyamatok szervezése és továbbfejlesztése mindennapi feladat, állandó az idővel való versenyfutás. Magyarországon az elmúlt években lezajló gazdasági és technológiai változások a szállítmányozás területén is jelentős kihívásokkal szembesitették az ágazat szereplöit. A legtöbb vezető a logisztikai költségek csökkentésében látta, vagy látja a megoldást, ami első körben segítette is a vállalatokat a versenyben maradásban, azonban az is nyilvánvalóvá vált, hogy szükség van fejlesztésekre, mivel hosszú távon csak ez tesz egy vállalatot sikeressé.

\section{Közúti áruszállítás}

A közúti fuvarozás szerepe jellemzően az 1990-es évektöl növekedett a vasúti szállítások háttérbe szorulásával. A hirtelen felgyorsult gazdaságban az elsődleges szempont a gyorsaság lett, ami a vasúti szállításokra nem volt jellemző, továbbá az újonnan létrejövő üzlethálózatok, gyárak és logisztikai központok nagyon kis számban rendelkeztek a vasúti szállításokhoz szükséges iparvágánnyal. A közút 
napjainkban is jelentős túlsúlyt képvisel a magyar áruszállításban, habár részesedése évek óta fokozatosan apad. Az Európai Unió célkitüzése, amit az ún. Fehér Könyvben fogalmazott meg, hogy a háromszáz kilométert meghaladó távolság esetén, az áruszállítást a közútról a vasútra és egyéb szállitási módokra kell átterelni. 2030-ra 30\%-ot és 2050-re 50\%-ot kell kiváltani más szállítási módokkal. Bár a közúti fuvarozásnak vannak a legmagasabb környezetszennyezési paraméterei, az utóbbi években egyre inkább domináns „zöld” gondolkodásmód ellenére is ez a fö árutovábbítási mód Európában.

A Központi Statisztikai Hivatal 2012-es adatai alapján a magyar szállítási ágazat tulajdonképpen megkezdte az elmozdulást ebbe az irányba. Habár a módozatok közül továbbra is messze a közúti részesedése a legnagyobb, részaránya a volument tekintve 2010 óta folyamatosan csökken. Míg 2010-ben az áruk 71,4\%át szállították közúton, addig egy évvel később 68,1\%-át, 2012-ben pedig csak 66,6\%- át (KSH, 2013) (1. ábra).

\section{1. ábra: Az áruszállítási teljesítmények megoszlása árutonna-kilométer alapján}

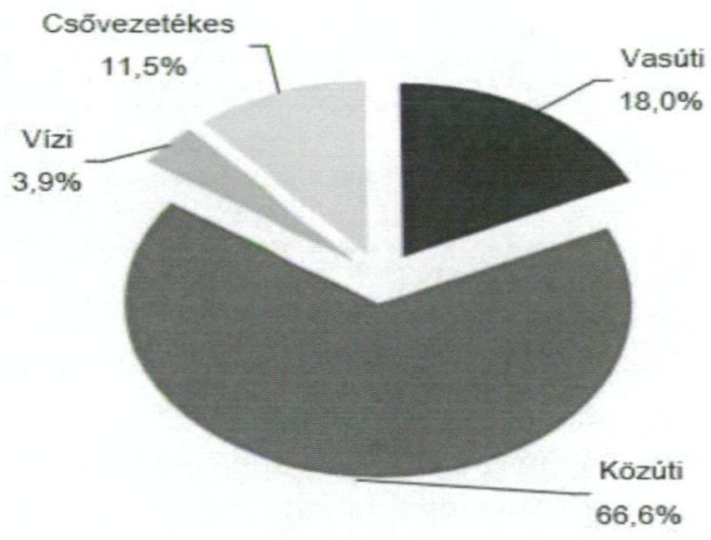

Forrás: Központi Statisztikai Hivatal (2013)

A közúti áruszállítás számos előnnyel bír, hiszen sủrü hálózattal rendelkezik, megvalósítható vele a háztól házig szállítás, átrakás nélkül, így az átrakásból adódó sérülési kockázatok is minimálisak. Széles áruskála szállítható vele, rugalmas, igény esetén könnyen módosítható az útvonal (Földesi, 2006). Ugyanakkor a gazdaságos szállítási távolságot a szakirodalom 750 km-re becsüli. Ezt a Központi Statisztikai Hivatal, 2012-es adatai is alátámasztják, hiszen az átlagos közúti szállítási távolság belföldön $70,4 \mathrm{~km}$, a nemzetközi fuvarozásban pedig $702,1 \mathrm{~km}$ volt 2012-ben.

Az elönyök mellett azért természetesen hátrányai is vannak ennek a szállítási módnak, amelyek a szállítmányozás szempontjából a következők lehetnek (Dankó, 2009):

- Nagy várakozási idők, kamionstop, határátkelők, balesetek miatt. 
- Az úthálózat túlterhelt, zsúfolt és balesetveszélyes, a közutak forgalma folyamatosan növekvő tendenciát mutat.

- Tömegáruk fuvarozása nem gazdaságos.

- A többi közlekedési ágazathoz képest leginkább élőmunka igényes.

- Nincs kötött díjszabás, fuvaronként alku tárgyát képezheti a fuvardijj.

- Függ az időjárási viszonyoktól, télen megnövekedhetnek a szállítási határidők.

- Rakomány tömeg (maximális 40 tonna), és méret korlátok.

- Bizonyos áruféleségek csak szigorú jogszabályi elöírások betartásával továbbithatók.

- Útvonal használati dijjak, behajtási engedélyek a szállítás költségeit növelik.

- Környezetszennyezés, kibocsátott gázok.

- EU-n kívüli országokba közlekedési engedély köteles.

2012-ben a különböző áruszállítási módozatokban 249 millió tonna árut mozgattak meg. Ez 7,4\%-kal kevesebb az előző évinél, ami illeszkedik a 2009 óta tartó csökkenő trendbe. Az árutonna-kilométeres teljesítmény eközben csupán 1\%kal mérséklődött, ami arra utal, hogy kevesebb árut szállítottak nagyobb távolságokra, azaz nőtt a nemzetközi szállítás részaránya. Magyarország fö partnerei a kiviteli forgalomban - az előző évivel megegyező sorrendben Ausztria, Németország, Olaszország, Szlovákia és Románia. A behozatali forgalomban a volument tekintve Németországból érkezik a legtöbb áru, míg Szlovákia megelőzte Ausztriát, Románia pedig Olaszországot a 2011. évi sorrendhez képest (KSH, 2013).

2. ábra: Áruszállítási teljesítmények szállítási módok szerint, EU 27

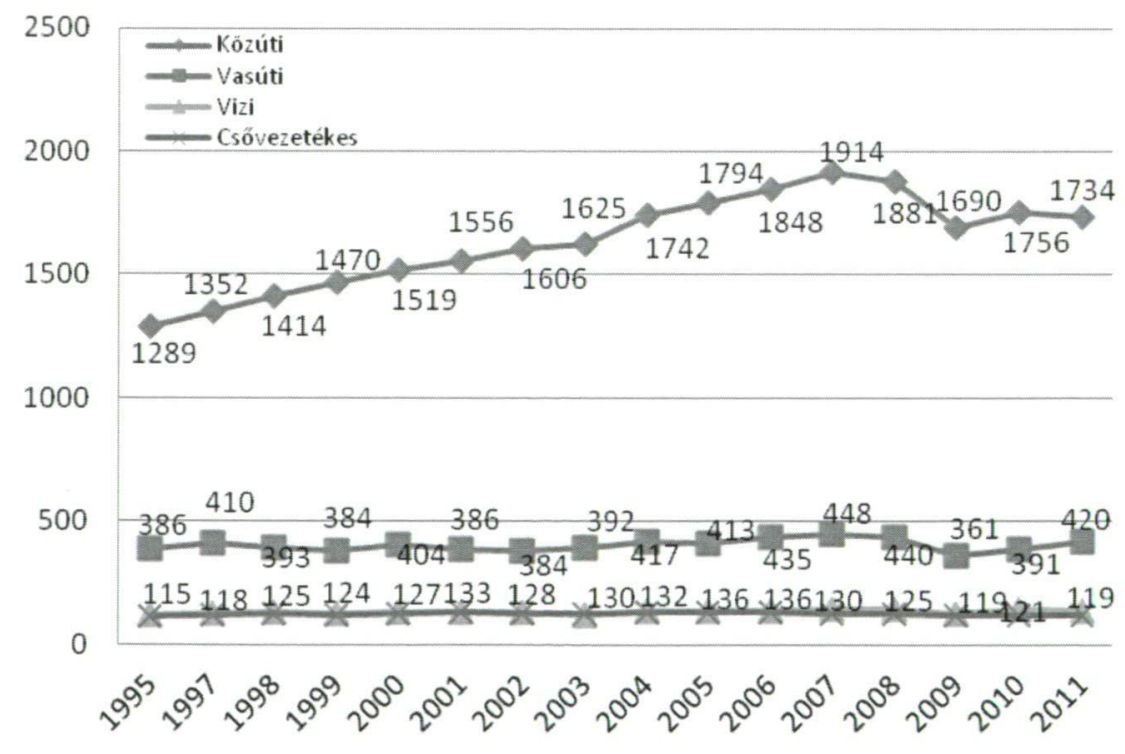

Forrás: KSH (2012) alapján saját szerkesztés 
A közút szerepe az Európai Unióban (EU) is számottevő, hiszen a teljes európai áruforgalom közel $70 \%$-a tehergépjármüveken történik (2. ábra). Az ábrán a piaci tendenciákat megfigyelve láthatjuk, hogy az EU 27 országaiban, mind árutonna kilométerben, mind árutömegben visszaesés tapasztalható a 2007 utáni időszakban. A 2009-es jelentős csökkenés azt mutatja, hogy a gazdasági világválság az áruszállítás piacát is érzékenyen érintette Magyarországon és Európában egyaránt.

\section{Az áruszállítási piac helyzete Magyarországon}

Hazánkban a földrajzi adottságok miatt a közúti ánuszállitás a legelterjedtebb szállítási módozat. A közúti árufuvarozást fötevékenységként végzö vállalkozások 2012-ben összesen 1086 milliárd Ft-os árbevételröl adtak számot, ami a teljes fuvarozási piac árbevételének 78\%-a. A teljesítmény korábbi évekhez viszonyított növekedését vélhetöen elsősorban a harmadik országok közötti fuvarozások növekedésével érték el a piaci szereplök. A szállítmányozási és logisztikai terület 9 milliárd Ft-os növekedést ért el 2011 -hez képest, 623 milliárd Ft-ot realizálva.

A közúti áruszállításban 2012-ben a cégek száma 8830 volt, ebből 824-en foglalkoztattak tíznél több munkavállalót. Az ágazatban alkalmazásban állók létszáma növekedett a korábbi évekhez képest. A 10 fönél több munkavállalót alkalmazó cégek adják a realizált árbevétel csaknem $80 \%$-át és foglalkoztatják az alkalmazottak 58\%-át. Az ágazati profit tekintetében elmondható, hogy míg korábban ez szinte teljes egészében a nagyobb cégeknek volt köszönhetö, addig 2012-ben már a profit 18\%-át követelték maguknak a tíz vagy annál kevesebb föt foglalkoztató cégek. A közúti árufuvarozók nyereségének pozitiv alakulását valószínüleg az e tevékenységre jellemzö jármülízingek visszaszorulása okozta. Jelentősen nőtt a hatékonyság is, hiszen míg 2008-ban 18 millió Ft jutott egy alkalmazottra, addig 2012-ben már 22,5 millió $\mathrm{Ft}$ volt az egy före jutó árbevétel. Ugyancsak javult a forgalomarányos nyereség (adózás elötti eredmény a forgalom százalékában).

A szállitmányozási és logisztikai ágazatban 2012-ben 1970 cég tevékenykedett, az átlagos foglalkoztatott létszám pedig 13844 fö volt. Az elért forgalomnövekedés közel 30\%-át, a 10 legnagyobb cég adta. Az ágazati sajáttőke 13\%-kal volt magasabb 2012-ben a korábbi évhez képest (Navigátor, 2014).

A közúti árufuvarozók tekintetében elmondható, hogy a vállalkozások száma 2012-ben jelentősen csökkent. Sokuk a gazdasági helyzet és a bizonytalan jövőkép áldozatának tekinthető - olvasható a NIT (Magánvállalkozók Nemzeti Fuvarozó Ipartestülete) 2012-es szervezeti és gazdasági beszámolójában (I1). 2011 végén még tízezer fölött volt a kizárólag belföldre érvényes engedéllyel rendelkező vállalkozások száma, egy évvel késöbb ez a szám már nem érte el a nyolcezret sem, a nemzetközi relációban dolgozó vállalkozások száma viszont alig mérséklödött. Folytatódik a jármūpark-koncentráció, ami a 2008-2009-es válság első évétől vált 
jellemzővé. 2011 végén egy fuvarozó vállalkozás átlagosan 3,8 jármüvet tartott üzemben, egy évvel késöbb 4,2 jármủvet.

\section{Vállalati környezet elemzése}

Környezeten a vállalati rendszerre ható tényezök összességét értjük. Azon hatásokat, feltételeket, elemeket, amelyek befolyásolják a vállalat (és a vállalatot alkotó személyek, csoportok) viselkedését, mozgásterét. A XXI. századtól egy úgymond turbulens környezet jellemzö, hiszen szinte egész iparágak alakulnak ki és tünnek el akár néhány év alatt. A vállalkozást körülvevő környezet réteges szerveződésü, ahol a széles környezetre (világgazdaság, nemzetgazdaság) a cégnek nincs ráhatása

A PEST (Political - Politikai, Economic - Gazdasági, Socio-cultural Társadalmi és Technological - Technológiai környezetet) elemzés során a vállalkozásra ható hosszabb távú környezeti tendenciákat vesszük számba és strukturáljuk. Ezáltal megragadhatóvá, kiemelhetővé válnak azok a fontosabb tényezök, amelyek befolyásolhatják a stratégiai döntéseket. Cél megtalálni a jelen és jövő azon környezeti tényezőit, amelyek a vállalkozás szempontjából meghatározóak (Chikán, 2008).

\section{Politikai környezet:}

- 2014-ben parlamenti választások Magyarországon, a kormány törekvése, hogy az ország ipari termelési központtá váljon. (A magyar ipar a GDP $23 \%$-át teszi ki, szemben az EU-átlag 15\%-kal).

- A gazdasági kapcsolatok épitése, megállapodás Törökországgal, a feltörekvő indiai gazdasággal kapcsolatokat építeni.

- A bankszektor tulajdonviszonyainak átalakítása (bankszektor 50\%-a hazai tulajdonban legyen).

- A munkát terhelö adók csökkentése, a fogyasztást terhelő adókra való áttérés.

- Az utóbbi években kiszámíthatatlanul változó jogi szabályozások: Polgári törvénykönyv változása 2014. március 15 .

- 2013-ban bevezetésre került az útdíj, ami a logisztikai költségek növekedésével járt.

- A használt jármüvek káros anyag kibocsátásának határértékeit szabályozó rendeletek (2009-töl Euro V, 2014. szeptembertől (tervezett) Euro VI bevezetése).

- A belföldi áruszállítás versenyképességének javitása érdekében az uniós minimumra csökkentették a légrugós jármüvek adóját, illetve mérséklödtek a helyi iparüzési adóterhek, hiszen az útdíj 7,5\%-a levonható a fizetendö helyi iparúzési adóból. 


\section{Gazdasági környezet:}

- A gazdasági válság nehezén lassan túllép a világ, de ez a magyar GDP alakulásán csak fokozatosan fog meglátszani.

- Az állami beruházások hatására erösödött az épitöipar.

- A külső konjunktúra (legföképp a nyugat-európai, föleg a német gazdaság élénkülésének) hatására átmenetileg javult az ipari termelés (elsősorban autóipar).

- A lassú gazdasági növekedés ellenére a vásárlóerő-paritás az európai átlagnak csak 38,9\%-a. A Globális Versenyképességi Index rangsora szerint Magyarország a 2011-ben elfoglalt 47. helyéröl 2013-ra a 60 . helyre esett vissza, és a prognózis szerint 2014-re a 63. helyezés várható.

- Hosszú fizetési határidők, rossz fizetési morál a belföldi árufuvarozás területén.

- A kisebb cégek nehezen jutnak finanszírozáshoz, például forgóeszköz hitelhez.

- Az EU által támogatott fejlesztési programok nem megfelelô kihasználása, több esetben az önrész hiánya miatt (pl. Gazdaságfejlesztési Operatív Program támogatásainak igénybevétele).

- Erösen hullámzó forint árfolyam.

- Az IMF (International Monetary Fund) 2014-es magyar inflációs várakozását $0,9 \%$-ra csökkentette.

- Az üzemanyag árak növekedése.

- Infrastrukturális fejlesztések: Közlekedési Operatív Program célkitüzései.

- Jövedékiadó-visszatérítés, a kereskedelmi gázolaj-ár magyarországi bevezetése.

\section{Társadalmi környezet:}

- A szakma és az oktatás közötti kommunikáció hiánya, aminek eredménye, szakképzetlen munkaerö.

- Kevés a gyakorlott, tapasztalt szállítmányozó szakember.

- Kommunikációs problémák, az idegen nyelvismeret Magyarországon nem elég elterjedt.

- Magas munkanélküliség egyes régiókban és elsősorban a kistelepüléseken.

- A munkaerő mobilitás alacsony szintje.

- Tévhit, félretájékoztatás, információhiány, ủjdonságtól való félelem.

\section{Technológiai környezet:}

- A versenyképesség romlása az elavult fuvarozói géppark miatt, magasak az új jármüvek beszerzési költségei.

- A kisméretű cégek körében alacsony a szállítmányozók informatikai támogatása, annak ellenére, hogy széles a támogatási megoldások skálája.

- Kevés a minősítéssel rendelkezö cégek száma, a nemzetközi vállalatok viszont elvárják a minősítéseket. 
- A technológia fejlödésével nem fejlödnek az ágazati részvevők, kevés a megújuló jármüpark, nem frissítik vagy cserélik az elavult technikai eszközöket (GPS, számítógépek).

- Lassan halad a mobil eszközök adta lehetöségek kihasználása, mivel a területen dolgozók csak kis része tudja ezeket az eszközöket kezelni.

\section{Elözmények és az e-útdíj bevezetésẻnek körülményei és hatásai}

Magyarországon a kormány és az érdekképviseletek már 2005 óta folytattak tárgyalásokat az e-útdij bevezetésével kapcsolatban. Ennek legföbb oka az, hogy míg a magyar fuvarozók kötelesek voltak e-útdíj fizetésére több európai országban, addig a külföldi tranzitáló jármüvek viszonylag olcsón vehették igénybe a magyar utakat. A tervek szerint Magyarországon 2008 januártól vezették volna be a használattal arányos elektronikus dijrendszert az autópályákon. Az EU 2007-ben elfogadott irányelvei szerint a 3,5 tonna össztömeg feletti jármüvekre 2009 júliusától kellett bevezetni az útdijat. Az EU területén belül jelenleg kétféle rendszer létezik. Az egyik a mikrohullám alapú GO-BOX rendszer, ami például Ausztriában is múködik. A jármüvek szélvédőjére kell rögzíteni egy eszközt, amelyet a dijellenőrző kapuknál lévő szerkezet olvas le. Elönye, hogy a fedélzeti egység olcsó és használata egyszerú, hátránya viszont az, hogy sok útmenti berendezésre van szükség, ezért a rendszer telepitése igen költséges. A másik rendszer müholdas technológián alapszik, ez kevesebb infrastruktúrát igényel, hátránya viszont, hogy nagyságrendekkel drágább a felhasználók számára.

Magyarországon az utóbbi rendszert vezették be, de a német utakon is ezzel a technológiával szedik be az útdíjat (Vakhalné, 2008).

Az országos közúthálózat forgalmi teljesítménye hazánkban 2000 és 2010 között majdnem 40\%-kal növekedett. $\mathrm{Ez}$ az úthálózat jelentös minőségbeli romlásához vezetett. Míg a korábbi években a fejlesztések finanszírozására inkább hazai források álltak rendelkezésre, addig az utóbbi években kizárólag EU-s forrásokat lehet bevonni a javítási költségek fedezésére. A költségvetésnek így nagy problémát jelentett az úthálózat karbantartása (Kuklai, 2013a).

A rendszer végül 2013. július 1-jén lépett életbe hazánkban. A hosszas tárgyalások ellenére, mégis meglepetésként érte a hazai fuvarozókat az e-útdíj bevezetése, ugyanis nem volt lehetőségük tesztidöszakra és sokan a technikai feltételeket sem tudták biztosítani a kért idöpontra. A két héttel a tervezett indulás előtt beérkező számtalan reklamáció és panasz miatt kétségessé vált az e-útdíj bevezetése, végül július 1 -jén elindult az új dijfizetési rendszer. Az érdekképviseletek szerették volna, ha a fokozatosság elvével vezetik be a rendszert, azaz elöször csak a 12 tonna feletti jármüvek után kell alacsonyabb dijat fizetni, de erre sem került sor. Hazánkban két és fél hónapjuk volt az érintetteknek a felkészülésre, míg Németországban két és fél évig tartott a tesztidőszak. A vállalkozóknak tehát a felgyorsított bevezetéssel és az irreálisan magas árakkal volt a legnagyobb problémájuk (a hazai e-útdij mértéke megegyezik az Ausztriában 
fizetendőével és ennél az összegnél Európában csak Svájc területén kell többet fizetni az úthasználatért) (Rojkó, 2013). Azonban az Európai Bizottság is felfigyelt arra, hogy a rendszer túl rövid idő alatt indult el: „a magyar hatóságok az uniós véleményezés elött életbe léptették az útdijrendszert, holott az uniós elöírások előzetes értesítést követelnek meg, mégpedig hat hónappal a bevezetés elött" (I2).

A Bizottság szintén kifogásolta a díjtételeket, miszerint azok nincsenek összefüggésben az infrastrukturális költségekkel, túl magasak, és kiszámításuk nehezen átlátható. Az Európai Bizottság mégsem talált kivetnivalót a rendszerben, sőt, a viszonylati jegyet, mint magyar újítást, a többi tagállamnak is átvételre ajánlotta (I3). Az e-útdij sikeres bevezetése a magyar innovációt és szakértelmet dícséri, hiszen az állam mellett sok hazai kis- és középvállalkozás vett részt a projekt kivitelezésében (Seszták, 2014).

Az új rendszer sajátossága a használatarányos útdij fizetése, ami előnyt jelenthet azok számára, akik kevesebbet használják az utakat. Kormányzati szempontból pedig a kategóriák szerinti besorolás és a köztük lévő dijkülönbségek meghatározásának fỏ célja az volt, hogy ösztönözze a fuvarozókat, a jármüpark megújítására, aminek gazdaságélénkítö hatása is van.

Az Állami Autópálya Kezelő Zrt. (ÁAK) által kihelyezett eszközökkel figyelik meg a fizetős útszakaszokon, hogy a járművek eleget tettek-e kötelezettségüknek. 74 darab fixen rögzített kapu, valamint 45 darab mobil, jármüvekbe telepitett egység segíti az ellenőrzést. A rögzített eszközöket országszerte elszórtan, illetve a határállomásokon helyezték el, míg az autókkal bármely útszakasz megfigyelhető.

Ezek a berendezések lehetővé teszik a forgalom megállás nélküli ellenőrzését. A kihelyezett kamerák minden jármüről két felvételt készítenek: egyet, amelyen a teljes szerelvény látszik és egyet, amelyen a rendszám. Ezen felül a müszer az áthaladó jármüvek legfontosabb adatait is rögzíti. Azonban akik a fedélzeti egységen keresztül intézik az útdij befizetését, azok bárhol és bármikor ellenőrizhetőek függetlenül attól, hogy van-e a közelükben ellenőrzőpont (Krausz, 2013).

A belföldi árufuvarozás területén azonban az e-útdíj bevezetésének hatására az eddigi költségek a többszörösére emelkedtek, hiszen a szabályozás elsősorban a 7,5 $\mathrm{t}$ össztömeget meghaladó jármüveket érintette. A bevezetés elött érvényben lévő díjszabást a 1. táblázat szemlélteti.

\section{1. táblázat: Magyarországi autópályák, autóutak és fỏutak használati díjai 2012-ben}

\begin{tabular}{|c|c|c|c|c|}
\hline kategória & napos & \multicolumn{1}{c|}{ heti } & havi & \multicolumn{1}{c|}{ éves } \\
\hline D1 & - & $2.975 \mathrm{Ft}$ & $4.780 \mathrm{Ft}$ & $42.980 \mathrm{Ft}$ \\
\hline D2 & $3.375 \mathrm{Ft}$ & $8.255 \mathrm{Ft}$ & $13.970 \mathrm{Ft}$ & $123.975 \mathrm{Ft}$ \\
\hline D3 & $3.375 \mathrm{Ft}$ & $12.600 \mathrm{Ft}$ & $20.370 \mathrm{Ft}$ & $184.985 \mathrm{Ft}$ \\
\hline D4 & $3.375 \mathrm{Ft}$ & $15.875 \mathrm{Ft}$ & $25.785 \mathrm{Ft}$ & $234.950 \mathrm{Ft}$ \\
\hline
\end{tabular}

Forrás: I4 
2013-tól a megtett úttal arányos dijfizetés mértéke a használt úttípustól (autópálya, autóút vagy föút), a gépjármű kategóriájától (J2, J3, J4) és környezetvédelmi besorolásától is függ. A járműkategóriák átalakítását a 3. ábra szemlélteti. A korábbi D2, D3, D4-es kategóriákat átalakították a J2, J3, J4-es dijkkategóriára.

\section{3. ábra: Új díjkategóriák 2013-tól}
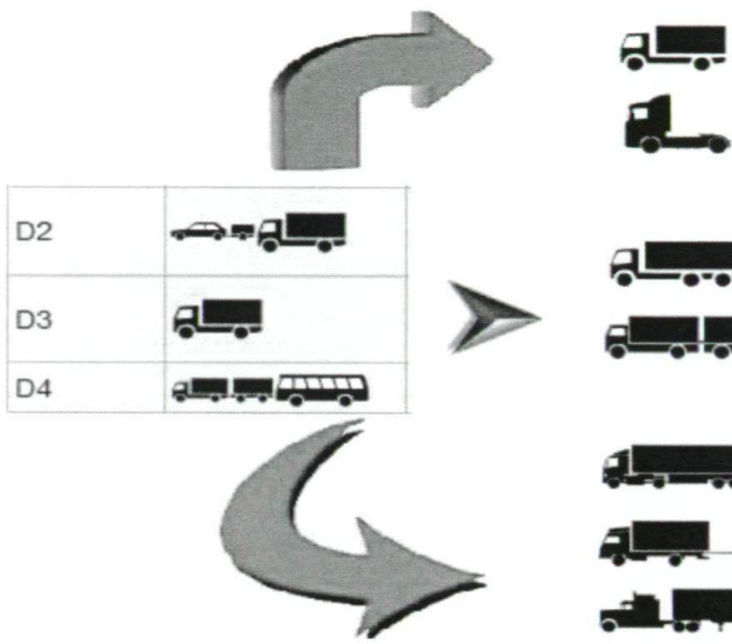

12 dijkategória

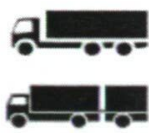

13 dijkategória
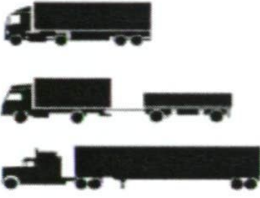

14 dijkategória

Forrás: I5

Ugyanakkor a korábbi rendszerhez képest csoportokat hoztak létre a környezetvédelmi besorolások szerint (2. táblázat). A C csoportba sorolhatóak az EURO I-es környezetvédelmi kategóriába tartozó jármüvek. Ezek fizetik jelenleg a legmagasabb útdijakat, mivel ők a leginkább környezetszennyezők. A második, B csoportba az EURO II-es besorolású autók kerültek egy alacsonyabb díjmértékkel. $\mathrm{Az}$ A csoportba pedig az EURO III, vagy annál jobb besorolásba tartozó jármúvek tartoznak a legkedvezőbb díjakkal.

A 2. táblázatban látható, hogyan változtak az éves költségek a bevezetés hatására egy korábban D4-es kategóriába sorolt nyerges jármüszerelvény esetén (5 tengely, $40 \mathrm{t}, 2,55 \times 4 \times 16,5 \mathrm{~m})$. Ha éves szinten $120000 \mathrm{~km}$ megtett úttal számolunk, akkor 2013 júliusa előtt a kilométerenkénti útdíj mértéke 1,96 Ft volt, amely a jelenlegi szabályozás mellett, besorolástól függően, $54-130 \mathrm{Ft} / \mathrm{km}-\mathrm{t}$ jelent. Megállapítható, hogy az elektronikus útdij bevezetésének hatására az úthasználatért fizetendő dij mértéke jelentősen emelkedett. 
2. táblázat: 2013. július 01-től J4-es díjkategória (4 vagy több tengelyes jármú) díjak összehasonlítása

\begin{tabular}{|c|c|c|c|}
\hline \multicolumn{4}{|c|}{ 2013. július 01-től J4-es díjkategória } \\
\hline Környezetvédelmi kategória & $A>=$ Euro III & B Euro II & C Euro I \\
\hline Föúton & $54 \mathrm{Ft} / \mathrm{km}$ & $68 \mathrm{Ft} / \mathrm{km}$ & $81 \mathrm{Ft} / \mathrm{km}$ \\
\hline Autópályán & $87 \mathrm{Ft} / \mathrm{km}$ & $108 \mathrm{Ft} / \mathrm{km}$ & $130 \mathrm{Ft} / \mathrm{km}$ \\
\hline Éves megtett távolság & $120000 \mathbf{~ k m}$ & & \\
\hline Környezetvédelmi kategória & A >= Euro III & B Euro II & C Euro I \\
\hline Föúton (éves ktg.) & $6480000 \mathrm{Ft}$ & $8160000 \mathrm{Ft}$ & $9720000 \mathrm{Ft}$ \\
\hline Autópályán (éves ktg.) & $10440000 \mathrm{Ft}$ & $12960000 \mathrm{Ft}$ & $15600000 \mathrm{Ft}$ \\
\hline \multicolumn{4}{|c|}{ 2013. július 01 elött D4-es díjkategória } \\
\hline Napos & Heti & Havi & Éves \\
\hline $3375 \mathrm{Ft}$ & $15875 \mathrm{Ft}$ & $25785 \mathrm{Ft}$ & $234950 \mathrm{Ft}$ \\
\hline
\end{tabular}

Forrás: Saját szerkesztés, 15

Ez egyes fuvarozóknak átmeneti likviditási problémát okozott, abból kifolyólag is, hogy az útdíj bevezetésekor csak elöre fizetésre volt lehetöség, a kisebb cégek pedig nem tudták ezt elöfinanszirozni. Ezért a Nemzeti Útdijfizetési Szolgáltató Zrt. (NÚSZ) 2014 januárjától megteremtette az utólagos útdij fizetés lehetóségét a megbizhatónak ítélt ügyfelek részére. Ez a konstrukció a stabil vállalkozásoknak lehetővé teszi, hogy akkor egyenlítsék ki a számlájukat - akár heti, kétheti vagy havi elszámolással - miután használják a dijköteles útszakaszt.

Emellett a kormány az árufuvarozók számára egy államilag támogatott forgóeszközhitel konstrukciót dolgozott ki. Az Állami Autópálya Kezelö Zrt-nél regisztrált kis-és középvállalkozások az általuk üzemeltetett, útdij fizetésre kötelezett gépjármüvekre, jármüvenként maximum 1 millió $\mathrm{Ft}-\mathrm{os}$, rulírozó jellegü azaz visszafizetés esetén ismételten, akár többször is igénybe vehető forgóeszközhitelt igényelhetnek az Útdíj Hitelprogram keretében. A konstrukció segít áthidalni az úthasználat előtt fizetendő útdij, és az akár 90 nappal később befolyó fuvardíj megérkezéséig tartó, likviditási nehézségeket okozó időszakot (I3).

Mivel az ágazatban igen nagy az árverseny, és a szolgáltatási dijak egyébként is alacsony szinten mozogtak, így egyértelmü volt a költségek áthárítása. Ezért az útdij bevezetéséről, annak hatásairól és az ehhez kapcsolódó áremelési javaslatról az ügyfeleket időben értesítették. Nagy hangsúlyt fektettek a kommunikációra, azonban az áremelkedés elfogadtatása nem volt zökkenömentes. Az is problémát okozott, hogy az útdij rendszer év közben indult, igy a megbizók egyfelöl azzal érveltek, hogy ez a dijtétel bizonyára már elöre beépítették a 2013-as árakba, másfelől pedig a következỏ évi ártárgyalásig szerették volna kitolni az átháríást. A fuvardij-emelés végül sikeresen ment végbe, több mint $80 \%$-ban tudta a cég 
átterhelni a költségeket a megbízókra. Ezt azonban rengeteg munka elözte meg: új ajánlatokat kellett késziteni, szerződéseket újratárgyalni, sőt azzal a problémával is szembesültek, hogy több kisebb fuvarozó nem tudta elöfinanszírozni az ủj terhet, ez pedig alvállalkozói szinten a rendelkezésre álló közúti fuvareszközök csökkenéséhez vezetett. Így a bevezetést követő átmeneti időszakban nagyobb időráfordítást igényelt a fuvarfeladatok szervezése, optimalizálása.

\section{Az e-útdíj és az iparúzési adó kapcsolata}

Az útdíj és az iparüzési adó viszonya nem egyszerü. A helyi adókról szóló 1990. évi C. törvény 40/A.§-át módosította a 2013. évi CIII. törvény $22 . \S$ (1) bekezdése, mely hatályba lépett 2013. július 1-től. Eszerint a székhely, illetőleg a telephely szerinti önkormányzathoz az adóévre fizetendő iparüzési adóból, legfeljebb azonban annak összegéig terjedően levonható az adóalany által ráforditásként, költségként az adóévben elszámolt, az autópályák, autóutak és föutak használatáért fizetendő, megtett úttal arányos dij (útdíj) 7,5\%-a. Azonban fontos megjegyezni, hogy az iparüzési adóból nem lehet levonni az autópálya matricáért fizetett ellenértéket és a külföldi autópályák, autóutak használatáért fizetett útdijat sem.

A fuvarozók részéről gyakran felmerül, hogy az útdíjat tovább kívánják számlázni a vevő részére, melynek kettős haszna lehet:

6.) A fuvarozás költségeinek jelentős növekedését tovább tudják háritani.

7.) Az úthasználati szolgáltatást közvetített szolgáltatásként kezelhetik az iparüzési adó meghatározásakor. Ez azonban nem lehet automatikus, figyelni kell a számla kiállításakor.

Miután az e-útdíj nem adókötelezettség, hanem egy szolgáltatás igénybevétele, a helyi adó törvényi elöírásainak a figyelembevételével lehet közvetített szolgáltatás is. Ehhez az kell, hogy az e-útdijat fizető társaság a belföldi vagy külföldi megrendelöjével irásban kötött szerzödésben állapodott meg, hogy az eútdijat részben vagy egészében külön tételben a fuvart megrendelö felé továbbszámlázhatja és ténylegesen is továbbszámlázza.

Ekkor az e-útdíjként fizetett összeg, illetve annak arányos része közvetített szolgáltatásnak minősül, és mint ilyen, csökkenti a helyi iparüzési adó alapját (I6).

\section{Az e-útdijfizetési rendszer gyenge pontjai a fuvarozók szemszögéből, javaslatok a problémák megoldására}

Az e-útdij bevezetése Magyarországon nem volt zökkenőmentes. Legnagyobb hiányosságként a tesztidőszak elmaradását említik az érintett vállalkozók. A rendszer gyors bevezetéséből adódó kellemetlenségek és fennakadások szintén a fuvarozókat terhelték. 
A Magyar Közúti Fuvarozók Egyesülete (MKFE) nem sokkal az e-útdij bevezetése után azonnali kezdeményezéssel fordult Németh Lászlóné fejlesztési miniszterhez, miszerint a használatarányos útdij-rendszer hibáit orvosolni kell.

Ezek közül az egyik legfontosabb intézkedés az útdij definiciójának módosítása lenne. A jelenlegi definíció: „az útdij az útdij-köteles elemi útszakasz megtételéért fizetendö, általános forgalmi adót is magában foglaló, a megtett úttal arányos úthasználat alapján az útdíj-szedö által kivetett dij." Azonban a fuvarozók tapasztalata szerint a 6500 kilométer dijfizetésre kötelezett útszakasz használatarányos megtételéhez a 2075 elemi útszakasz kevés, hiszen sorozatosan tapasztalhatók a meg nem tett kilométerek utáni befizetések.

A viszonylati jegyet igénybe vevő mikrovállalkozások esetében problémát okoz az, ha telephelyükön felrakodnak, a legközelebbi jegyvásárlási lehetőségig szabálytalanul közlekednek. Ennek elkerülése érdekében az MKFE javaslata az, hogy a mikrovállalkozásoknak a regisztrációt követően lehetösége legyen megjelölni legalább három, a környezetükben lévő viszonylati jegyértékesítő pontot, hogy az odáig tartó útszakaszon ne büntessék őket (Kuklai, 2013b).

$\mathrm{Az}$ elektronikus fizetési mód is számos fuvarozónak okozott bosszúságot mindamellett, hogy anyagilag is terhes volt számukra a rendszer beindulása. Számos panasz érkezett az egyenlegfeltöltésre, elöfordult 2-3 napos átfutási idő is. Márpedig folyamatosan figyelni kell az egyenleget, hiszen ha elfogy az egység a rendszerből, azonnal büntethető a jármü. Gyakori volt a túlszámlázás, bizonyos útszakaszok többszöri figyelembevétele, amely hibák ahhoz vezettek, hogy a feltöltéseknek lényegesen meg kellett haladniuk az elöre kalkulált útdíj összegét. Nem lehetett látni a pénzmozgást, csak az egyenleg változását és utóbbiból találgatni azt, hogy mennyi a felhasznált pénzösszeg. A felsorolt fizetéssel kapcsolatos problémák az idő elörehaladtával csökkentek, de teljesen nem szüntek meg.

$\mathrm{Az}$ útvonaltervezés is sok bosszús percet okozott a soföröknek. A fedélzeti eszköz ugyanis egy elöre eltervezett útvonalat kalkulál, amely alapján történik az útdíj végleges összegének kiszámítása. A rendszernek azonban vannak hiányosságai, úgymint nem ismeri jó néhány nagy ipari park címét és kerülövel tervez, amelybe plusz fizetős szakasz is beleesik, vagy nem veszi figyelembe a súlykorlátozást és tiltott területre irányitja a jármüvet. Legjelentősebb problémája viszont az MKFE-hez érkező panaszokból leszürve az, hogy nem engedi a rendszer az útvonal, illetve a célállomás megváltoztatását. Azaz megengedi, de az elöre befizetett pénzböl nem kapnak vissza. Tehát ha több le- és felrakó hely van az országban, vagy változik a cím, a célállomás, változik maga az útvonal is, a rendszerben nem szerepel olyan opció, hogy az elöre befizetett útdijból a fuvarozó visszakapjon és a tényleges úthasználat után fizessen. Ez egyébként ellentétes a hazai és nemzetközi fuvarozási szabályokkal is, amelyek lehetővé teszik, hogy az áru feladója utólagos rendelkezési jogával éljen, tehát jogában áll például a célállomást megváltoztatni.

A soförök, akik saját börükön tapasztalták a rendszer indulásakor kialakult zürt, a hiányos tájékoztatást említik egyik legfóbb problémaként. A benzinkutaknál 
az alkalmazottak sokszor nem tudtak a soförök segítségére lenni, a viszonylati jegy váltására alkalmas kioszkokat nem tudták használni, illetve megfelelő nyelvủ tájékoztatót sem tudtak kiadni. A külföldi soförök arra panaszkodtak, hogy hivatalos állami szervektỏl semmilyen tájékoztatás nem érkezett a magyarországi e-útdij bevezetéssel kapcsolatosan, egyedül az MKFE információi alapján az IRUtól (International Road Transport Union) tudtak előzetes hírekhez jutni (Krausz és Horváth, 2013).

\section{A műszaki és informatikai eszközök fejlödésének hatásai a közúti szállításra}

Az elmúlt 10-15 évben több olyan technikai eszköz is megjelent a piacon, amely támogatja az áruszállitás folyamatát, a szervezést, a nyomon követést, vagy figyeli a jogszabályok betartását.

$\mathrm{Az}$ informatikai fejlettséget illetően jelenleg még elég nagy a szakadék az ezen a területen tevékenykedő, nagyobb vezető cégek és a többséget alkotó, kis és középvállalatok között. Nyilvánvaló kiindulási pont egy olyan globális IT (információs technológia) szállító megtalálása, amelynek gyakorlata van a webvagy felhöalapú hosting területén is. Ajánlatosabb eleve olyan rendszert telepíteni, amely már alaphelyzetben testre tudja szabni a teheráru-fuvarozásával kapcsolatos feladatokat, a vámeljárást vagy a szállítmányfigyelést. $\mathrm{A}$ felhőalapú számítástechnika (cloudcomputing) vagy a web-hosting irányába történő elmozdulást a tökehiánnyal küszködő vállalkozások „kényszerítették ki”, ily módon elkerülve a jelentős költségeket, amelyek a hagyományos telephelyen müködö informatikai rendszerekkel együtt járnak, beleértve az ezeket felügyelö szakszemélyzet bérét is. Ez jó példa arra, hogy milyen módon járulhat hozzá a gyenge gazdasági környezet a technológiai fejlődéshez.

Jelenleg a vállalati együttmüködések során az adat és információ a legkülönbözöbb kommunikációs csatornákon (telefonon, papiron, emailben, faxon) áramolhat a felek között. Egyesek fejlett vállalatirányitási rendszerekkel rendelkeznek, és közvetlenül kapcsolódnak más vállalatok hasonló rendszereihez, de ez nem széles körben elterjedt.

Magyarországon az elektronikus útdij bevezetésével egy időben jelent meg az On Board Unit (OBU) fedélzeti egység, amely a használatarányos útdij fizetést segíti. Az OBU észleli, ha a fuvarozó díjköteles úton tartózkodik, és a gépjármü regisztrált beállításai alapján (melyet a www.hu-go.hu oldalon regisztrálhat) automatikusan kifizeti a megfelelö összeget. Az OBU használata sokkal előnyösebb, mint az útdij fizetésére szintén alkalmas viszonylati jegy, mivel így a valósan megtett útszakaszok után az egyenlegből vonják le. A viszonylati jegy esetében az elöre megtervezett útszakaszra elöre kell fizetni, ami ha útközben módosul, akkor nincs mód visszaigénylésre. A módosult útszakaszra pedig új viszonylati jegyet kell váltani, ami többletköltséget jelent.

Az Electronic Data Interchange (EDI) - vagyis elektronikus adatcsere - üzleti dokumentumok (pl. megrendelések, számlák) küldését és fogadását teszi lehetővé 
üzleti partnerek számítógépei között, meghatározott formátumban. Ezek szigorúan strukturált üzenetek számítógépek között, emberi közremüködés nélkül. Az EDI az üzleti partnerek elektronikus dokumentumainak küldésére és fogadására vonatkozó szabványnak tekinthetö. Ezek alapján megállapítható, hogy a fenti eszközök alkalmazása pontosabb, költséghatékonyabb és gyorsabb információáramlást tesz lehetővé, amely hosszú távon a vállalat versenyképességét is növeli.

\section{A szállítmányozó piac kérdőíves vizsgálata}

A szállítmányozó piac vizsgálata akkor lehet teljes körü, ha maguktól az érintett cégektől kapunk információkat. Annak érdekében, hogy felmérjem az ágazatban dolgozók véleményét a piac jelenlegi helyzetéről, a verseny alakulásáról, illetve az arra ható tényezőkről, egy online kérdőíves kutatást végeztem. Célcsoportjaim a közúti fuvarozás és szállítmányozás területén működő magyar kis- és középvállalkozások voltak. 56 válasz érkezett, 60\%-ban 10 fönél kevesebb alkalmazottat foglalkoztató cégektől.

$\mathrm{Az}$ áruszállításban tevékenykedő cégek gazdasági helyzetének változását az elmúlt 5 évben a 4. ábrán szemléltetem.

\section{4. ábra: Az áruszállításban tevékenykedô cégek gazdasági helyzetének változása az elmúlt 5 évben}

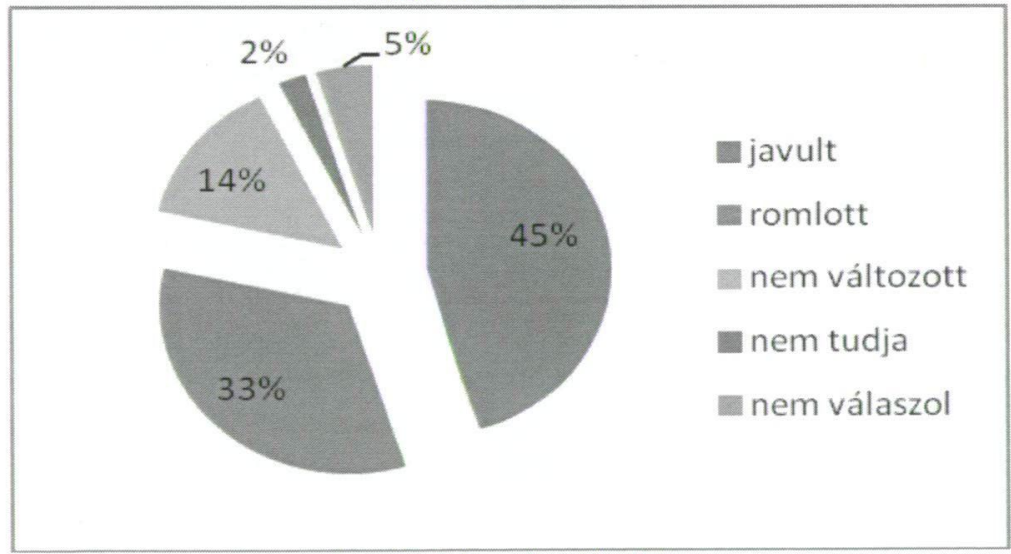

Forrás: Saját felmérés, 2014

A felmérés alapján a cégek $45 \%$-a itélte meg úgy, hogy javult a vállalatuk versenypozíciója, 33\% szerint viszont romlott a helyzetük. Ez az arány azt mutatja, hogy a gazdasági válság nehezén lassan sikerül túllépni, azonban egyes cégek még mindig nehézségekkel küzdenek. Ennek oka lehet a szállítási volumen visszaesése, illetve az is, hogy a fizetési fegyelem csökkenése emelkedő költségekkel párosult.

Itt elsősorban az elektronikus útdij bevezetésére kell gondolni. Ugyanakkor a növekvő fuvardíjak okán a megbízók egyre inkább az olcsóbb megoldásokat keresik, kiélezve ezzel a versenyt a szállítmányozók és a fuvarozók között. 
Véleményem szerint azoknál a cégeknél ahol javulás következett be, a növekedés a piacról kieső versenytársak megbizásainak megszerzésével magyarázható.

Az e-útdíj rendszer bevezetésével az úthasználatért fizetett díjak a sokszorosára emelkedtek, ezért fontosnak tartottam megvizsgálni, hogy mindez hogyan hatott a cégek költségszerkezetére, milyen mértékben tudták érvényesíteni az útdíj költségeket a közúti áruszállítók (5. ábra).

\section{5. ábra: Milyen mértékben tudták érvényesíteni az útdíj költségeket közúti áruszállítók?}

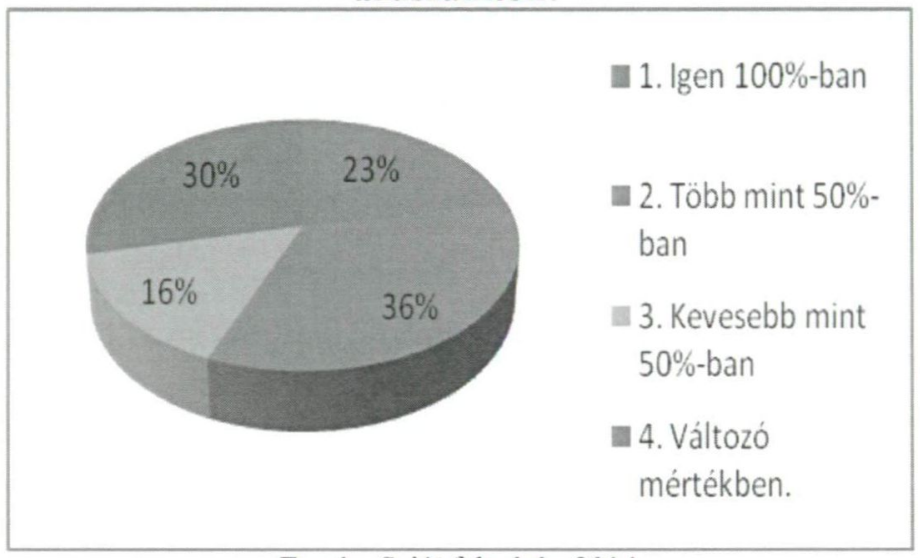

Forrás: Saját felmérés, 2014

A válaszokból kiderült, hogy a megkérdezett vállalkozások 23\%-a 100\%-ban, valamint 36\%-a több mint 50\%-ban átháritotta az útdijat a megbízókra. A gyakorlat azt mutatja, hogy a 2013. július elsején bekövetkezett bevezetés mindezt nagyban nehezítette, mivel a megrendelök igyekeztek kitolni az áthárítást a 2013 év végéig, az új ártárgyalásokig, vagy azzal vádolták a fuvarozókat, hogy az útdijat már előre beépítették az aktuális árakba. Másik fontos tényező, hogy a megrendelö csak a saját rakomány útvonalára hajlandó többletköltséget fizetni.

Az útdijjjal kapcsolatban azt is vizsgáltam, hogy a fuvarozók hogyan tudták megfinanszírozni az előre fizetésből adódó hirtelen jött terheket. Mint kiderült, a válaszadók $61 \%$-ának nem volt szüksége külső segítségre, $11 \%$ pedig hitelt vett fel.

A Nemzetgazdasági Minisztérium az Útdíj Hitelprogram kidolgozásával igyekezett segíteni a kis- és középvállalkozókat. Azonban, mint a válaszokból is látszik, ez nem volt igazán vonzó a cégek számára, ráadásul a program jókora késéssel indult. Bizonyos esetekben előfordult még, hogy a megbízók az útdijat előre kifizették. Ebben az esetben viszont fontosnak tartom megjegyezni, hogy mindez csak hosszú távú üzleti kapcsolatok esetében müködőképes.

A piaci változásokhoz való igazodás és a hatékonyság egyik fontos területe az új technológiák követése és alkalmazása, illetve a megfelelő információ áramlás biztosítása. Ezért fontosnak tartottam megvizsgálni, hogy milyen informatikai háttérrel és vállalatirányitási rendszerrel rendelkeznek az áruszállítást végző cégek. 
A válaszadók $65 \%$-a számítástechnikai ellátottságát, fejlettségét közepesnek ítélte, fuvarszervezést támogató informatikai rendszerrel azonban csak $14 \%$ rendelkezik. Jórészt saját, egyedi igényeiknek megfelelő programokat használnak, míg egy kis részük a piacon megvásárolható „dobozos” szoftvereket alkalmazza.

$\mathrm{Az}$ informatikai ellátottság aránya azonban összességében igen alacsonynak mondható. A fejlődés irányait maguk a cégek is látják, hiszen arra a kérdésre, hogy véleményük szerint milyen logisztikai tendenciák vannak megjelenöben a magyar piacon, a legtöbben az információs és kommunikációs technológiák általánossá válását, illetve a fejlett logisztikai rendszert, mint versenyelönyt jelölték meg. Az informatikai fejlettsẻg alacsony szintje vélhetően a vállalatok költségszerkezetének összetételében keresendő. A legtöbben elötérbe helyezik az adók, üzemanyag, útdij és a karbantartási költségek fedezését, amelyek a jellegükböl adódóan szükségesek a müködéshez. Az informatikai fejlesztések azonban az esetek többségében háttérbe szorulnak, mivel ezek befolyásolhatóak vagy elhalaszthatóak.

$\mathrm{Ez}$ az eredmény nem sokban különbözik az NRC Kft., 2012-es kutatási eredményeitől. Az ötven fönél kisebb cégek $61 \%$-ánál a cégvezetök az informatikát nem tartják stratégiai területnek. A magyar kisvállalkozások költségszerkezetében 2\%-ot jelent az informatika. Az ötven fönél kisebb magyar cégek vezetői közül minden nyolcadik cégvezető gondolja, hogy a cége fejlett IT-megoldásokat használ. A felmérésböl kiderül, hogy az ötven fönél kisebb cégek $58 \%$-a öt évnél is korosabb számítógéppel rendelkezik, ez igaz a szoftverekre is, hiszen azokat javarészt a gépekkel együtt vásárolták (I7).

$\mathrm{Az}$ ágazatban megfigyelhető tendenciákat vizsgálva a válaszadók úgy vélik, hogy a jövő bizonytalansága miatt egyre többen fognak felhagyni a fuvarozással és szállítmányozással. Ezt a tendenciát a NIT (Magánvállalkozók Nemzeti Fuvarozó Ipartestülete) 2012-es szervezeti és gazdasági beszámolója is alátámasztja, mely szerint 2012-ben a közúti árufuvarozásban jelentősen csökkent a vállalkozások száma. 2011 végén még tízezer fölött volt a kizárólag belföldre érvényes engedéllyel rendelkezök száma, egy év múlva viszont már nem érte el a nyolcezret sem. Mivel a nemzetközi relációban dolgozóknál alig volt csökkenés, ezért arra lehet következtetni, hogy a tendencia föként a belföldi fuvarozást és szállitmányozást érinti.

A fejlesztések, befektetések irányát tekintve költséghatékonyságot növelö, illetve a szolgáltatások minőségének javítását célzó intézkedésekben látják a cégek a fejlődés lehetöségét. Az egyre élesebb versenyben, ahol az ügyfelek a korábbinál jóval körültekintőbben kalkulálnak, még több ajánlatot kérnek be egy-egy fuvarfeladatra, a lehető legolcsóbb megoldást keresve, a költségek csökkentése a piaci pozíció javulását eredményezheti. Emellett a cégek minőségi szolgáltatások nyưjtásával lesznek képesek magukat megkülönböztetni a konkurenciától. 


\section{0. Összegzés}

A vizsgálat során megállapítottam, hogy Magyarországon a szállítási teljesítmények tekintetében 2009 óta megfigyelhetö csökkenés, föként a belföldi áruszállitás volumenének visszaesésével magyarázható, aminek fö oka a fuvarozók versenyképességének romlása. Ez elsősorban abból adódott, hogy a fizetési fegyelem csökkenése emelkedő költségekkel párosult. A költségek tekintetében az elektronikus útdij bevezetésének hatásaira forditottam kiemelt figyelmet, hiszen ez a tényező jelentős többletterhet rótt a vállalkozásokra, és az elöre finanszirozás is többeknek problémát okozott. A fuvarozók helyzetének alakulása a szállítmányozókat is jelentős mértékben befolyásolta, hiszen a megbízások teljesítésénél legtöbb esetben alvállalkozókra támaszkodnak. Az elektronikus útdij bevezetésével olyan mértékben nőttek a költségek, hogy a nagy árverseny miatt már addig is alacsony árak következtében, ennek akár részben történö nem áthárítása is veszteséget jelentett volna fuvarozónak és szállítmányozónak egyaránt.

$\mathrm{Az}$ áthárítás során azonban jelentős problémát okozott a rendszer év közbeni indulása, hiszen a megbízók egyfelöl azzal érveltek, hogy ez a dijtétel bizonyára már beépitették a 2013-as árakba, másfelöl pedig a következő évi ártárgyalásig szerették volna kitolni az átháritást. Az ágazat támogatásának szükségességét a kormány is felismerte, hiszen az elmúlt években több intézkedés is született. A Nemzeti Útdíjfizetési Szolgáltató Zrt. (NÚSZ) 2014 januárjától megteremtette az utólagos útdijfizetés lehetőségét, a kormány pedig egy államilag támogatott forgóeszközhitel konstrukciót dolgozott $\mathrm{ki}$, amely segit áthidalni az úthasználat elött fizetendő útdíj, és a sokszor hónapokkal később befolyó fuvardij megérkezéséig tartó, likviditási nehézségeket okozó időszakot. Ezen lépések hatásait a közúti fuvarozás és szállítmányozás területén müködő magyar kis- és középvállalkozások körében vizsgálva arra a megállapításra jutottam, hogy többségük mégsem élt ezzel a lehetőséggel. Feltehetően a szigorú hitelminősítési követelmények miatt.

Véleményem szerint a felgyorsult információáramlás korszakában a cégek informatikai fejlettsége szintén hatással van a versenyképességre. Megvizsgálva a kérdést, az derült ki, hogy jelentös lemaradás tapasztalható ezen a téren. A magyarázat feltehetően a vállalatok költségszerkezetének összetételében keresendő, hiszen azoknál a cégeknél, amelyek pénzügyileg instabilak, a fejlesztések háttérbe szorulnak. Ez azonban sajnos egy ördögi kör, mivel a változásokhoz való alkalmazkodás és versenyben maradás legfontosabb területei a termék- és szolgáltatás innováció, az új technológiák, valamint az üzleti folyamatok optimalizálása.

A jövöbeli fejlödés iránya lehet a kommunikációs eszközök összekapcsolása a vállalatirányítási rendszerrel, továbbá az elektronikus adatcsere alkalmazása, amely lehetővé tenné, hogy a megrendelő folyamatos jelentést kapjon az áru helyzetéről, meghatározott idöközönként, mindezt emberi közremúködés nélkül.

Összességében elmondható, hogy a jól szervezett folyamatok növelik a cég hatékonyságát és a megbizó elégedettségét, a fejlett technológiai háttér, a piaci 
trendek naprakész ismerete és a kellö rugalmasság együtt pedig, a siker és a versenyképesség fenntartásának kulcsa lehet.

\section{Irodalomjegyzék}

Chikán A. (2008): Vállalatgazdaságtan. Aula Kiadó Kft., Budapest.

Dankó L. (2009): Marketing-logisztika. Miskolci Egyetem Marketing Mühely, Miskolc

Földesi P. (2006): Logisztika I-II. jegyzet. Széchenyi Istvản Egyetem, Györ.

Központi Statisztikai Hivatal (2013): Jelentés a szállítási ágazat helyzetéröl, 2102. Statisztikai tükör, 7 (96.), $1-10$.

Krausz J. (2013): Az e-útdij túl van a harmadik hónapon. Autó közlekedés, Budapest. 25. 2013. november 4. 6-7.

Krausz J., Horváth G. M. (2013): E-útdij: a pénzbeszedés müködik, a rendszer kevésbé. Autó közlekedés. 2013. 25. augusztus 2. 7-13.

Kuklai K. (2013a): Stratégiai megállapodás. Autó közlekedés. 25. 2013. augusztus 2. 3.

Kuklai K. (2013b): Konfliktusok helyett megoldandó feladatok. Magyar Közlekedés. 21 (13), 3.

Navigátor (2014): 22 (3)

Rojkó J. (2013): Az e-dij nem lehet más, mint a fuvarköltség része. Magyar Közlekedés. 21 (11). 5.

Seszták M. (2014): Egyéves az e-útdíjrendszer. Navigátor. 22. (7-8) 30.

Vakhalné P. M. (2008): Nemzetközi szállitmányozási és fuvarozási szakismeretek II. PC-Line Stúdió Kft. Budapest.

I1: NIT (Magánvállalkozók Nemzeti Fuvarozó Ipartestülete) 2012-es szervezeti és gazdasági beszámolója. <http://www.nit.hu/index.php/rolunk/kueldetes-misszio>

I2: HVG: Eljárással fenyegeti Magyarországot Brüsszel az e-útdij miatt In: <http://hvg.hu/gazdasag/20130904_Eljarassal_fenyegeti_Magyarorszagot_Bruss\#rss>

13: Magyar Nemzet Online: $A z$ Európai Bizottság is ajánlja a magyar újítást In.: $<$ http://mno.hu/gazdasag/az-europai-bizottsag-is-ajanlja-a-magyar-ujitast-1 196978>

I4: Adó online: Kovácsné Á. J. Az e-ítdij és az iparüzési adó. <http://ado.hu/rovatok/ado/az-e-utdijes-az-iparuzesi-ado>

I5: Magyarországi autópályák, autóutak és fôutak használati dijai 2012-ben. <http://autopalya.hu/>

I6: Uj dijkategóriák 2013. <http:// www.nemzetiutdij.hu/>

I7: Az ütdij hitelprogram - kedvezményes hitel, még egyszerübben. <http://www.utdijhitel.hu/>

I8: Informatikai öskorban dolgoznak a magyar kisvállalkozások. $<$ http://nol.hu/gazdasag/informatikai_oskorban_dolgoznak_a_magyar_kisvallalkozasok1448343> 